\title{
EFFECT OF THE SELF-PURIFICATION OF OUM ER RBIA RIVER ON THE ELIMINATION OF FISH RELEASES \\ KHADIJA OUAISSA ${ }^{1,2, *}$, Assia KRITIHII, ${ }^{1,}$,Youness.OUMESSOUD, Abdelaziz MAYCHAL ${ }^{2}$ and Mustapha HASNAOUI ${ }^{1}$ \\ ${ }^{1}$ Environnemental engineering Team. Department of Biology, Faculty of Sciences and Techniques .University Sultan MoulaySlimane. M' Ghila, B.O 523. 23000 Beni-Mellal, Morocco \\ ${ }^{2}$ Fish Farming Ain Aghbal, Azrou-Morocco \\ Corresponding author*: Email: khadijaouaissa89@gmail.com \\ * Phone number: +212666109480
}

\section{ABSTRACT}

Fish farming is a rapidly growing production worldwide, where it covers nearly $50 \%$ of fish inputs for human consumption. Releases to the natural environment are also an important issue, especially as they are visible and quantifiable, being emitted directly into the water.

The physicochemical analyzes of the various Oued Er-Rbia points (ES, P1, P2, P3 and E4) show that the physico-chemical quality of the water downstream of the OumEr-Rbia magnification station shows no signs of deterioration of the receiving releases.

Fish farming effluents are known to deteriorate the quality of freshwater and the excessive presence of nitrogen and phosphorus in the water leads to eutrophication of the environment. This is not the case at the Oum Er-Rbia station, but it is crucial to develop food formulations that cause the least amount of nitrogen and phosphorus released into the environment.

\section{INTRODUCTION}

Breeding Fish stations face major challenges, the most important of which is the reduction of the negative impacts of discharges on the environment. It is mainly a sustainable development of the industry through clean practices in line with recommended regulations.

The negative environmental impacts of aquaculture are very numerous, but the most worrying is the eutrophication of fish receiving effluents from aquaculture farms (Persson 1991, Correll 1998, Ouellet 1999 and Vandenberg 2001). The main pollutants involved in this phenomenon are phosphorus, nitrogen, and suspended organic matter (Correll, 1998).

The discharge waters of fish farms have a direct impact on the degradation of the receiving environment, causing the eutrophication of effluentreceiving streams in aquaculture farms (Persson 1991, Correll 1998, Ouellet 1999, and Vandenberg 2001). Phosphorus, nitrogen and suspended solids are the main contributors to this phenomenon (Correll, 1998).

Environmental concerns about aquaculture have led researchers to explore ways and means to make aquaculture a viable and sustainable activity to enable it to continue playing the important role in aquaculture. global supply of fish products. At the exit of fish farms, quality standards for rejected water are imposed. They constitute limits for the size of the breeding and the possibilities of production. The treatment of discards leaving fish farms contributes to the reduction of the impacts of livestock effluents.

For fish farms to become profitable, most fish farmers need to intensify production, use water to the maximum and maintain high inventories of fish. This intensification of fish farming could lead to some environmental impacts. 
The composition of fish feed, their digestibility and the feed conversion rate largely determine the level of discards due to fish activity, and therefore the release into the environment of organic matter and nutrients (phosphorus and nitrogen) (Ackefors). and Enell, 1994). These can lead to changes in ecosystems, particularly eutrophication of aquatic environments.

The risk of eutrophication of the environment by fishing activities is a hindrance to the development of several fish farms. Several fish farmers are aware of these constraints and eager to provide solutions. But often they do not know the importance of their releases.

The project of the Ain Aghbal company which is the subject of the present work, proposes to contribute to the challenge by exploring a comparative trial of three foods (A, B and C) and evaluate their effects on Oued Oum Er-Rbia. The overall objective is to obtain significant results in terms of production growth and reduction of fish releases.

This work is also aimed at determining the variability of the main physicochemical parameters of the water discharged by the rainbow trout breeding station in Oum Er-Rbia.

\section{Material and methods}

\subsection{Geographical location}

Domaine Ain Aghbal, one of the private agricultural estates in Morocco is located $3 \mathrm{~km}$ west of the city of Azrou, It is located on the pure and natural waters of the source Ain Aghbal.

This area has two fish farming stations, station of transformation of trout in filets and station in Azrou and a grow-out station near the sources of Oum Er-Rbia, located 70km from the city of Azrou. The extension station of Oum Er-Rbia, commonly known as the Oued to 40 sources. Station of Oum Er Rbia located on the left of the Oum Er-Rbia river , the latter are fed by a water table crossing salt soils. However, this water, although salty, does not have the same composition as seawater with absence of iodine and other salts.

This station has a breeding capacity of $600 \mathrm{~m}^{3}$ and a production capacity of 140 tonnes / year. Two separate water pipes serve the freshwater and saltwater basins.

\subsection{Test basins}

6 differents shaped basins to carry out our experimentation, 4 basins in square shape (BCA, $\mathrm{BCB}, \mathrm{BCC}$ and $\mathrm{BCD}$ ), with a volume of $8 \mathrm{~m}^{3}$ and 2 basins of rectangular concrete form (B1 and B2) with a volume of $45 \mathrm{~m}^{3}$.

The supply water flow rate (Oum Er-Rbia spring water) is $11.47 \mathrm{~m}^{3} / \mathrm{h}$ and $76.51 \mathrm{~m}^{3} / \mathrm{h}$ respectively at the 4 polyster basins and 2 concrete basins.

The water renewal time is the same level of all basins.Sampling of basin water.

Figure 1: Location of sampling points.

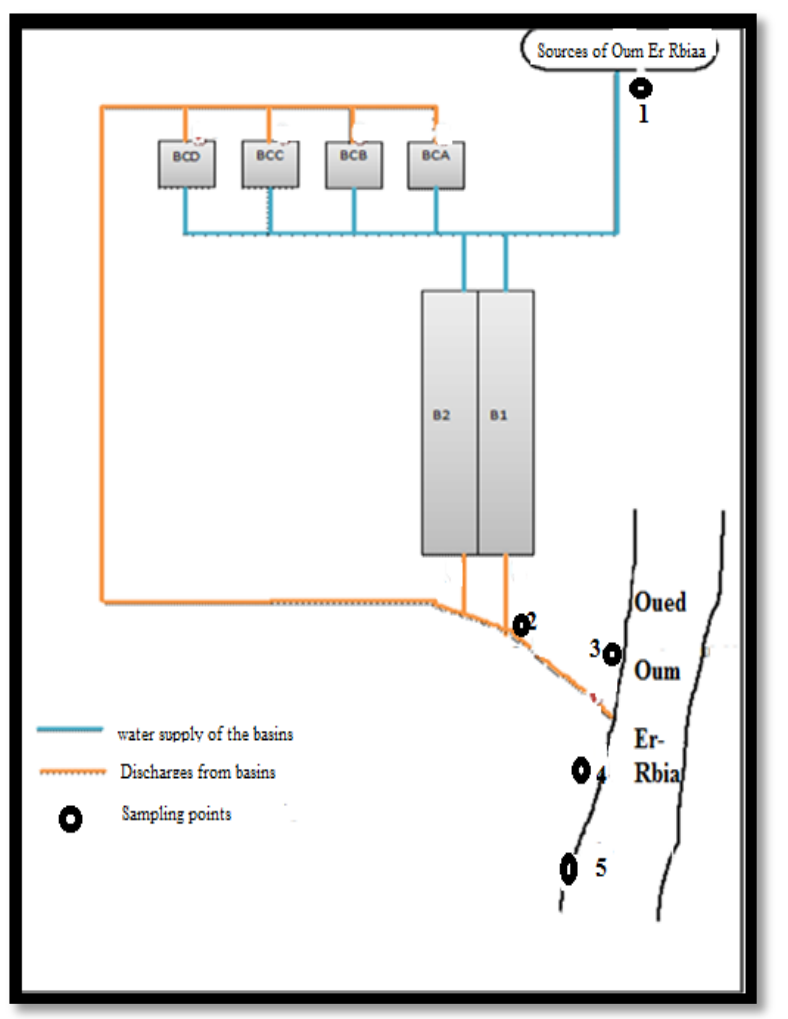

5 points of analysis are retained for the monitoring of the quality of the water. The Oum Er-Rbia river measuring stations are identified by stakes driven into the bottomof the river. 
Table 1: Water sampling points.

\begin{tabular}{|c|l|}
\hline Sapmles & \multicolumn{1}{|c|}{ Sampling points. } \\
\hline SW & Spring water \\
\hline P1 & $\begin{array}{l}\text { Point of interaction of the waters of square } \\
\text { and rectangular basins }\end{array}$ \\
\hline P2 & $\begin{array}{l}1 \text { meter before the point of the confluence of } \\
\text { the waters of the test basins and Oued Oum } \\
\text { Er-Rbia }\end{array}$ \\
\hline P3 & $\begin{array}{l}1 \text { meter after the confluence of the waters of } \\
\text { the test basins and Oued Oum Er-Rbia }\end{array}$ \\
\hline P4 & 50 meters after the confluence point \\
\hline
\end{tabular}

Chemical analyzes of the water were performed upstream and downstream of the six test basins (BCA, BCB, BCC, BCD, B1 and B2).

To estimate the concentrations of ammoniacal nitrogen, nitrites, nitrates, orthophosphates, suspended solids and chemical oxygen demand at the outlet of the basins, 5 water samples were taken at a bimonthly frequency.

These water samples are then transported in a cooler at $4{ }^{\circ} \mathrm{C}$ to the analysis laboratory of the Oum Er-Rbia Hydraulic Basin Agency (ABHOER) of Beni-Mellal.

\begin{tabular}{|c|c|c|c|c|c|c|}
\hline & $\begin{array}{c}\mathrm{NH}_{4}^{+} \\
(\mathrm{mg} / \mathrm{l})\end{array}$ & $\begin{array}{c}\mathrm{NO}_{2}^{-} \\
(\mathrm{mg} / \mathrm{l})\end{array}$ & $\begin{array}{c}\mathrm{NO}_{3}^{-} \\
(\mathrm{mg} / \mathrm{l})\end{array}$ & $\begin{array}{c}\mathrm{PO}_{4}{ }^{3-} \\
(\mathrm{mg} / \mathrm{l})\end{array}$ & $\begin{array}{c}\mathrm{MES} \\
(\mathrm{mg} / \mathrm{l})\end{array}$ & $\begin{array}{c}\mathrm{DCO} \\
(\mathrm{mg} / \mathrm{l})\end{array}$ \\
\hline $\mathrm{S}$ & $\begin{array}{c}0.029 \pm \\
\mathrm{W}\end{array}$ & $\begin{array}{c}0.003 \pm \\
0.002\end{array}$ & $\begin{array}{c}5.03 \pm \\
2.311\end{array}$ & $\begin{array}{c}0.036 \pm \\
0.022\end{array}$ & $\begin{array}{c}5.333 \pm \\
2.388\end{array}$ & $9 \pm 4.60$ \\
\hline $\mathrm{P} 1$ & $0.43 \pm$ & $0.127 \pm$ & 19.09 & $0.23 \pm$ & $29.79 \pm$ & $54.97 \pm$ \\
& 0.32 & 0.090 & \pm 8.33 & 0.13 & 10.23 & 21,21 \\
\hline & $4,23.10$ & $1.9 .10^{-}$ & $2.49 \pm$ & $1.2 .10^{-3} \pm$ & $4.76 \pm$ & $7.61 \pm$ \\
$\mathrm{P} 2$ & $\begin{array}{c}-3 \pm 5.9 . \\
{ }^{3} \pm\end{array}$ & $\begin{array}{c}0.97 \\
10^{-4}\end{array}$ & $9.10^{-4}$ & $1.2 .10^{-4}$ & 1.67 & 3,04 \\
\hline $\mathrm{P} 3$ & $0.032 \pm$ & $0.079 \pm$ & $5.19 \pm$ & $0.027 \pm$ & $19.55 \pm$ & $5.9 \pm$ \\
& 0.01 & 0,065 & 2.85 & 0.010 & 4.58 & 2.56 \\
\hline & $0.02 \pm 0$. & $\begin{array}{c}3,310^{-} \\
{ }^{3} 2.210^{-}\end{array}$ & $5.03 \pm$ & $0.030 \pm$ & $5.33 \pm$ & $10 \pm$ \\
$\mathrm{P} 4$ & 012 & 3 & 2.31 & 0.019 & 2.38 & 5.20 \\
\hline
\end{tabular}

Table 2: Average values of the physical parameters of the feed water from the sampling points

\subsection{Discard analysis of the fish station}

To estimate the outflows of nitrogen $\left(\mathrm{NH}_{4}{ }^{+}\right.$, phosphorus $\left(\mathrm{PO}_{4}{ }^{3-}\right)$ and suspended matter at the inlet and the outlet of basins, water samples are taken twice per month consecutively. Samples are transported, in a cooler at $4^{\circ} \mathrm{Cand}$ analyzedin thelaboratory of the OumEr-Rbia hydraulic basin agency in Beni-Mellal.

According to AFNOR (1983),Ammonia nitrogen was measured by the acidimetric method after distillation (NFT90-015); orthophosphates by spectrophotometry after mineralization followed by acid hydrolysis (NFT 90-013) and suspended matter by filtration method on fiberglass filter disc (NFT 90-105).

\section{Résultats}

The temperature, $\mathrm{pH}$, electrical conductivity and dissolved oxygen water of the source and the different sampling points in Oum Er Rbia river were measured in situ. The results are given in the table below.

\begin{tabular}{|c|c|c|c|c|}
\hline & $\mathrm{T}^{\circ} \mathrm{C}$ & $\mathrm{O}_{2}(\mathrm{mg} / \mathrm{l})$ & $\mathrm{pH}$ & $\begin{array}{l}\text { Electrical } \\
\text { conductivity } \\
(\mathrm{S} / \mathrm{cm})\end{array}$ \\
\hline $\mathrm{SW} *$ & $14.88 \pm 0.70$ & $9.53 \pm 1.66$ & $7.51 \pm 0.50$ & $216.73 \pm 12.91$ \\
\hline $\mathrm{P} 1$ & $14.02 \pm 0.32$ & $10.12 \pm 1.17$ & $7.15 \pm 0.13$ & $213 \pm 10.23$ \\
\hline $\mathrm{P} 2$ & $14.5 \pm 0.4$ & $11 \pm 1.12$ & $7.87 \pm 0.45$ & $190 \pm 10.67$ \\
\hline $\mathrm{P} 3$ & $14.31 \pm 0.60$ & $11.6 \pm 0.34$ & $8.1 \pm 0.10$ & $190.55 \pm 14.58$ \\
\hline $\mathrm{P} 4$ & $13.5 \pm 0.012$ & $10.5 \pm 1.13$ & $8.12 \pm 0.19$ & $210 \pm 12.38$ \\
\hline
\end{tabular}

ablTable 3 : monitoring of the rainbow trout breeding station in he different sampling points in Oum Er Rbia river

* SW : Spring Water

The results of the bimonthly analyzes of the physical parameters of spring water (point 1) show that during the monitoring period, the trout were under optimum conditions according to the rainbow trout breeding standards (Tabl. 1).

Indeed, during the test period, the average water temperature recorded a value of $14.88^{\circ} \mathrm{C} \pm 0.70$ in the optimum range of trout water quality standards. Moreover, the feed water of the Oum Er-Rbia river breeding station comes from the source of Oum Er- 
Rbia which is characterized by thermal stability all year.

The dissolved oxygen measured at the inlet of the station shows a fairly high average content of the order of $9.60 \mathrm{mg} / 1 \pm 1.66$ thus showing that the fish are in optimal conditions of saturation with dissolved oxygen.

For $\mathrm{pH}$, it was noted that the average values are between 7 and 8.5 , meeting the required standards for trout farming.
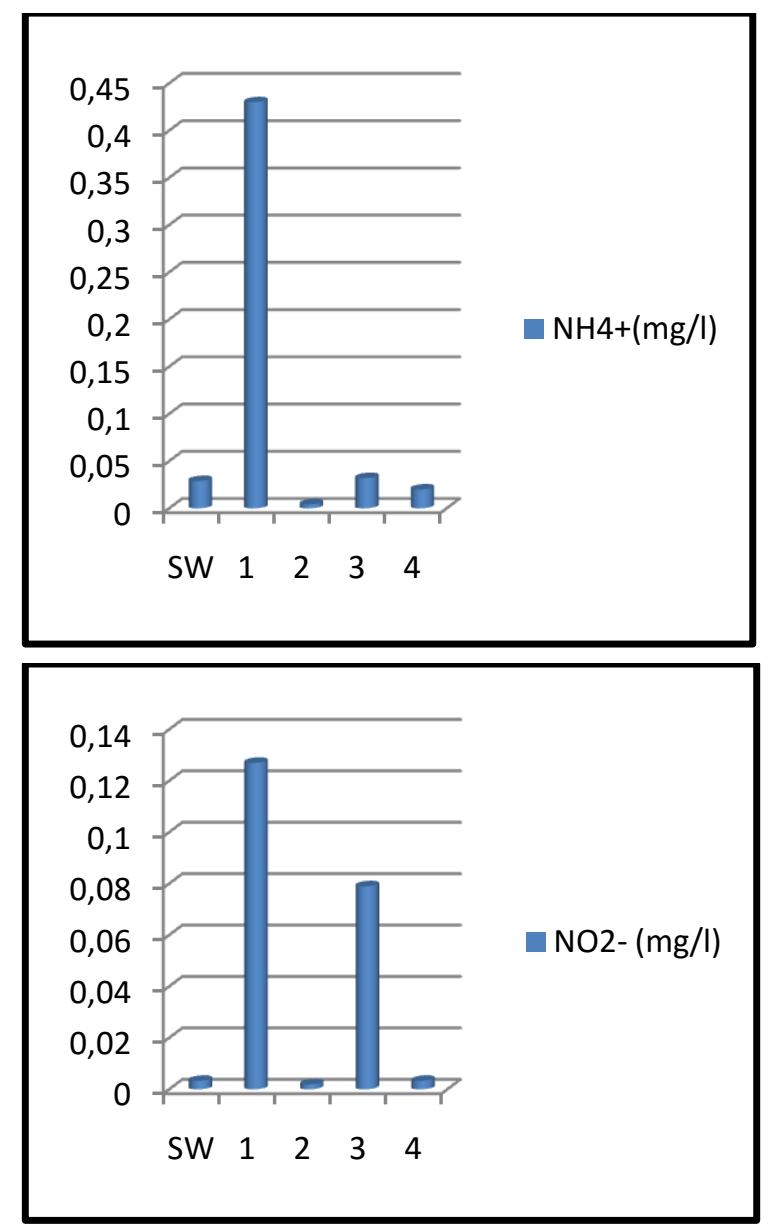
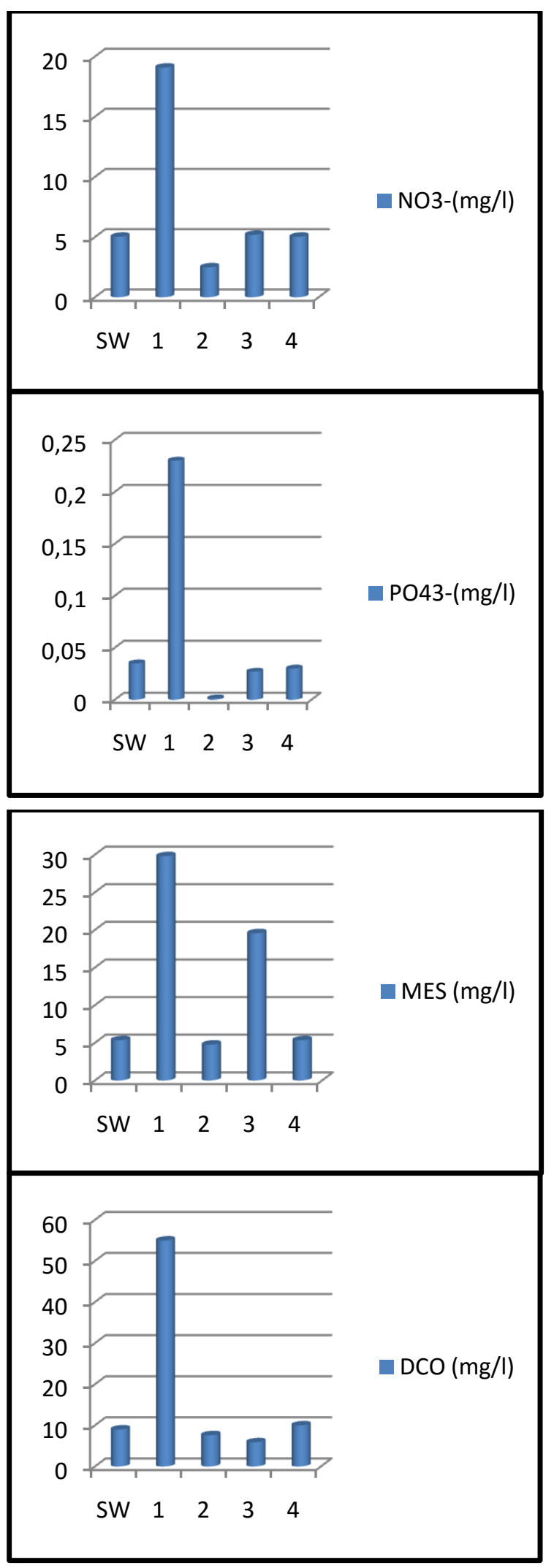

Figure 2: Concentrations of ammoniacal nitrogen, nitrates, nitrites, orthophosphates, chemical oxygen demand and suspended solids in the various points of Oum Er Rbia river

At the point 1 sampling point we recorded the highest levels of ammonium, nitrates, nitrites, 
orthophosphates, suspended solids and chemical oxygen demand.

In fact, point 1 is the mixing point of the pond discharges of the three feedstocks, which explains the high nitrate, MES, nitrite, the suspension matter and the phosphorus.

At the point 2 the concentrations of the rejected elements are very low compared to 1 .

In point 3 , the analyzed elements represent the cumulation of those which arrive from the source basins and those of origin the sources of Oum ErRbia.

Further downstream, the concentrations recorded at point 4 are comparable to those found at the inlet feedwater with high but acceptable levels of COD. From the above figure it is noted that point 1 (the point of confluence of rainbow trout ponds) has a high concentration of ammonia nitrogen, nitrates, nitrites, orthophosphate and suspended in relation to other points $(2,3$ and 4$)$ in contrast to point 4 which has low concentrations of releases that are comparable to concentrations found in spring water. The monitoring of the evolution of the quality of the aquifer has been shown to be optimal for fish life and not exceeding the limited values for the rainbow trout.

\section{Discussion}

Fish production has the particularity of being the animal production most closely related to the environment in which it is practiced. Its development depends on a supply of good quality water, with good physical properties (temperature, oxygen, $\mathrm{pH}$, electrical conductivity) and chemical properties (acceptable concentrations of $\mathrm{NH} 4+$, NO2-, NO3-, PO43- and MES) and free from toxic and microbiological products that can play a role as vectors of pathogens responsible for the devastating diseases of fish production (Guyennet, 2000).
Standard room temperature (SAT) is the temperature at which maximum growth and yield of food is achieved. In rainbow trout, this temperature is $15^{\circ} \mathrm{C}$ (Piper et al., 1982). Rainbow trout grow at a much slower rate at $7^{\circ} \mathrm{C}$ than at $15^{\circ} \mathrm{C}$ (Ducateau 2015). At temperatures continuously at or below $9^{\circ} \mathrm{C}$, trout farming would probably not be profitable (Bernard, 2010).

The temperature values measured at the Oum ErRbia magnification station are between 13.2 and $15.5^{\circ} \mathrm{C}$. They are favorable to the growth of rainbow trout, these results corroborate with those obtained by Darschnik and Schumacher (1987) show that the temperature can increase significantly during the summer months and the enrichment in nitrogen and phosphate is important.

This value is close to that recorded in the feed waters of the Oum Er-Rbia grow-out station, averaging $14.16 \pm 0.76^{\circ} \mathrm{C}$.

Dissolved oxygen is another important abiotic parameter because it conditions the living condition of aquatic organisms. Its content can be critical, especially in deep and slightly agitated environments (Arrignon, 1998).

At the magnification station, the feed water is well oxygenated with contents of $9.53 \pm 1.66 \mathrm{mgO}_{2} / 1$. This confirms the values of Raleigh et al. (1984) and Arrignon (1998) who reported that salmonids survive better in habitats with a dissolved oxygen concentration greater than $7 \mathrm{mg} / 1$. Pittenger (2002) found that the Gila trout (Oncorhynchus Gilae) behaves better in an environment where the dissolved oxygen concentration is greater than $9 \mathrm{mg}$ $/ 1$.

The distribution of electrical conductivity levels at the feedwater level is affected by the concentration of sodium chloride in the source water since the majority of Oum Er-Rbia sources flow through salt soils. Its electrical conductivity is $216.73 \pm 12.91$ $\mu \mathrm{s} / \mathrm{cm}$. 
The $\mathrm{pH}$ is $7.51 \pm 0.50$. It is influenced by the temperature of the water during the different seasons.

The water from the springs is of excellent quality in terms of mineralization, with a relatively stable $\mathrm{pH}$ and an optimal average temperature which ensures a good stability of the breeding conditions.

The suspended solids in the feed water have low values hardly exceeding $6 \mathrm{mg} / 1$. These weakeners are related to the feedwater that comes directly from the sources of Oum Er-Rbia. Nevertheless, these values are favorable for rearing of trout in the magnification phase, which requires a concentration of suspended solids of less than $25 \mathrm{mg} / 1$ (Sigma, 1983).

Despite these low concentrations, the high flow rates of fish releases can however bring a not negligible load locally in the receiving environment, particularly if it is already enriched.

Orthophosphates with a peak at point E2 may be the main factor responsible for eutrophication and environmental dystrophication (Ouellet, 1999).

The concentration of orthophosphates is positively correlated with temperature and salinity. In our case, the stability of the temperature and the $\mathrm{pH}$ acts positively on the variations of the rejections.

Mantzavrakos et al (2007) demonstrated that the distribution of ammonia may be related to changes in physical parameters such as temperature, salinity, and water density. On the other hand, these high levels may be due to over feed and fish metabolism. According to studies by Kormas et al (2000), nitrates are used rapidly by phytoplankton in summer, which explains the negative correlation of nitrate content with temperature.

Nitrates represent the second cause of the development of eutrophication. In the majority of cases, phosphorus and nitrates occur together in fresh or salt water that is closed or not renewed. In our case, the flow of the Oued is strong and the renewal of water in the basins is frequent which explains the important reduction of the rejections.

As is often cited in the literature (UMA Engineering 1988, Stechey and Trudell 1990, Westers 1991, Cripps 1994, Cripps and Kelly 1995), it was also observed in our study that fish effluents are easily biodegradable. and are diluted relative to other fields of industrial activity (Ouellet, 1998).

In addition, the dynamism of rivers can affect the distribution of nutrient salts (Pitta et al., 2005). These results corroborate those found at points E3 and E4 where the high flow of the wadi has allowed a dilution of the discharges.

Thus, the self-purifying power of the wadi Oum ErRbia prevails since it is upstream of the Oued where the sources of pollution are non-existent and where the turbulence of the water is maximum (saturation in dissolved oxygen ).

\section{Conclusion}

The minimization of particulate discharges from the farming system is more complicated and today less studied than that of industrial and domestic liquid discharges.

The monitoring of the evolution of the quality of the output waters of the rainbow trout breeding basins showed that the physicochemical parameters vary in the recommended standards of fish release. The physicochemical analyzes of the different Oued Er-Rbia wadi points (P1, P2, P3 and P4) show that the physico-chemical quality of the water downstream from the Oum Er Rbia shows no signs of deterioration of the receiving medium.

Fish farming effluents are known to deteriorate the quality of freshwater and the excessive presence of nitrogen and phosphorus in the water leads to eutrophication of the environment. This is not the case at the Oum Er-Rbia station, but it is crucial to develop food formulations that cause the least 
amount of nitrogen and phosphorus released into the environment.

\section{REFERENCES}

1. Ackefors, H., M. Enell., 1994. The release of nutrients and organic matter from aquaculture systems in Nordic countries. Journal of Applied Ichthyology, $10: 225-241$.

2. AFNOR., 1983. Recueil de normes françaises des eaux : méthodes d'essais. Paris.

3. Arrignon J., 1998. Aménagement piscicole des eaux douces, $5^{\text {éme }}$ éd. (Paris : Lavoisier, TEC \& DOC).

4. Barnabé G., 1991. Bases biologiques et écologiques de l'aquaculture. Ed. Lavoisier, Paris, 500

5. Bernard J., 2010. Guide de la truite arc en ciel, de la biologie à l'élevage p.213

6. Cripps S.J., 1994. Minimizing outputs: treatment. Journal of Applied Ichthyology, 102 : 84-294.

7. Cripps, S.J., L.A. Kelly., 1995. Effluent treatment to meet discharge consents. Trout News, $20: 15-24$.

8. Darschnik V.S., Schumacher H., 1987. Trout farms causing disturbance in the natural stream continuum. Archiv für Hydrobiologie, 110, 409439.

9. Dosdat A., Le Ruyet J P., Coves D., Dutto G., Gasset D., Le Roux A and Lamarie G ., 2003. Effect of chronic exposure to ammonia on growth, food utilisation and metabolism of the European sea bass (Dicentrarchuslabrax). Aquat Living Resour.16 (6):509520.https://doi.org/10.1016/j.aquliv.2003.08.001

10. Einen O., Roem A J.,1997. Dietary protein/energy ratios for Atlantic salmon in relation to fish size: growth, feed utilization and slaughter quality. Aquaculture Nutrition 3, 115-126.

11. Kormas K A., Nicolaidou A., Reizopolou S.,2000.Temporal variations of nutrients chlorophyll a and Particulate Matter in three coastal Lagoons of Amvrakikos gulf (Ionian Sea, Greece). Mar Ecol 22:201-213.

12. Mantzavrakos E ., Kornaros M., Lyberatos G ., Kaspiris P .,2007. Impact of marine fish farm in Agrolikos Gulf (Greece) on the water column and the sediment. Desalination 210: 110-124.

13. MorinR., 2012. Qualité de l'eau requise pour l'élevage des salmonidés. Document d'information DADD-14. Ministère de l'Agriculture, des Pêcheries et de l'Alimentation. 25 p. http://www.mapaq.gouv.qc.ca/Fr/Peche

14. Ouellet G., 1999. Les rejets des stations piscicoles et leurs impacts environnementaux. Ministère de l'Agriculture, des Pêcheries et de l'Alimentation, 45p.

15. Persson G., 1991. Eutrophication resulting from salmonid fish culture in fresh and salt waters : Scandinavian experiences. DANS : C.B. Cowey et C.Y. Cho (eds.). Nutritional Strategies and Aquaculture Waste. Proceedings of the First International Symposium on Nutritional Strategies in Management of Aquaculture Waste. University of Guelph, Guelph, Ontario, p. 163-185.

16. Piper R.G., Mc Elwain I.B ., Orme L.E ., Mc Craren J.P., Fowler L.G., Leonard J.R., 1982. Fish hatchery management, U.S. Fish and Wildlife Service, Department of the Interior, p. 134.

17. Pitta P, Apostolaki E T., Giannoulaki M., Karakassis I., 2005. Mesoscale changes in 
the water column in response to fish farming zones in three coastal areas in the eastern Mediterranean Sea. Estuar Coast Shelf S 65: $501-512$

18. Raleigh R.F., Hickman T., Solomon R.C et Nelson P C., 1984. Habitat Suitability Information: Rainbow Trout. U.S. Fish Wildlife. Servo FWS/OBS-82/10.60.

19. Sigma Environmental Consultants Ltd., 1983. Summary of water quality criteria for salmonids fishes, Department of Fisheries and Oceans, SECL 8067, p. 36-48.

20. Stechey D. et Y. Trudell., 1990. Aquaculture wastewater treatment : wastewater characterization and development of appropriate treatment technologies for the Ontario trout production industry. Rapport préparé par Canadian Aquaculture Systems pour Ministry of Environment, Environmental Services, Water Ressources Branch, Toronto, Ontario. 88 p. +5 annexes.

21. UMA Engineering Ltd., 1988. Waste water treatment in aquaculture facilities. Rapport déposé à Ministry of Environment, Water Reasources Branch, Toronto, Ontario. 61 p.

22. Vandenberg G.W., 2001. Encapsulation de la phytase microbienne: Influences sur la disponibilité de nutriments chez la truite arcen-ciel. Thèse de doctorat, Université Laval, Québec, $277 \mathrm{p}$.

23. Westers H., 1991. Operational waste management in aquaculture effluents. DANS : C.B. Cowey et C.Y. Cho (eds.). Nutritional Strategies and Aquaculture Waste. Proceedings of the First International Symposium on Nutritional Strategies in Management of Aquaculture Waste. University of Guelph, Guelph, Ontario, p. 231- 238
24. Young C. C., Bureau D $. P \quad, 1998$.

Development of bioenergetic models and the Fish-PrFEQ software to estimate production, feeding ration and waste output in aquaculture, Aquatic Living Resources. 11(4):199-210. https://doi.org/10.1016/S09907440(98)89002-5. 